\title{
SOSIALISASI KEBIJAKAN KAWASAN TANPA ROKOK (KTR) DI RSUD LUBUK PAKAM DELI SERDANG
}

\author{
Balqis Wasliati ${ }^{1}$, Ika Nur Saputri ${ }^{2}$, Delita Br Panjaitan ${ }^{3}$, Raisha Octavariny ${ }^{2}$, \\ Christina Octavia ${ }^{3}$ \\ ${ }^{1}$ Program Studi Kesehatan Masyarakat Program Magister, \\ Institut KesehatanMedistraLubukPakam \\ ${ }^{2}$ Program Studi Kebidanan, Institut Kesehatan Medistra Lubuk Pakam \\ ${ }^{3}$ Program Studi Kesehatan Masyarakat, Institut Kesehatan Medistra Lubuk Pakam
}

JIn. Sudirman No.38 LubukPakam, Kabupaten Deli Serdang,
Sumatera Utara - Indonesia
*email korespondensi author: balqiswasliati@medistra.ac.id

DOI $10.35451 /$ jpk.v1i1.714

\begin{abstract}
Kawasan tanpa rokok (KTR) merupakan kebijakan yang dibuat oleh Kemenkes untuk mencegah dan mengendalikan dampak kesehatan yang disebabkan karena merokok. Pengendalian dampak kesehatan bukan hanya berlaku pada perokok aktif, tetapi juga perokok pasif dan lingkungan sekitar yang terpapar asap rokok. Metode pelaksanaan dengan metode sosialisasi berupa pemahaman tentang kondisi perokok di Indonesia dan tentang KTR. Selain itu dilakukan dengan sesi tanya jawab dan wawancara kepada tenaga kesehatan dan pengunjung terkait rokok dan KTR. Pelaksanaan kegiatan ini dibagi menjadi tiga tahapan yaitu, perencanaan, pelaksanaan dan evaluasi. Keseluruhan tenaga kesehatan dan masyarakat memahami tentang bahaya merokok namun tetap melaksanakan kegiatan merokok dengan alasan kecanduan dengan rokok. Sosialisasi KTR memberikan pemahaman bahwa RSUD Deli Serdang memiliki peraturan untuk menerapkan dan mendukung KTR yang dikeluarkan oleh pemerintah melalui Kemenkes.
\end{abstract}

Kata Kunci: kebijakan tanpa rokok, kebijakan kesehatan

\begin{abstract}
Non-Smoking Area (KTR) is a policy made by the Ministry of Health to prevent and control the health impacts caused by smoking. Control of health impacts does not only apply to active smokers, but also passive smokers and the surrounding environment exposed to cigarette smoke. The implementation method with the socialization method is an understanding of the condition of smokers in Indonesia and about KTR. In addition, it was conducted with a question and answer session and interviews with health workers and visitors related to cigarettes and KTR. The implementation of this activity is divided into three stages, namely, planning, implementation and evaluation. All health workers and the public understand the dangers of smoking but still carry out smoking activities on the grounds of addiction to cigarettes. KTR socialization provided an understanding that Deli Serdang Regional Hospital had regulations to implement and support KTR issued by the government through the Ministry of Health.
\end{abstract}

Keywords: Non Smoking area; Health policy 


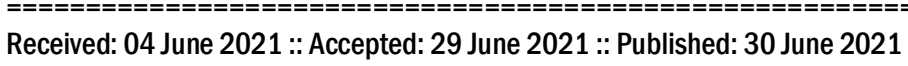

\section{Pendahuluan}

Menurut Kemenkes (2011) menyatakan bahwa kawasan tanpa rokok (KTR) merupakan ruangan atau area yang dilarang untuk kegiatan merokok, dan mempromosikan tembakau. KTR merupakan kebijakan yang dibuat oleh Kemenkes untuk mencegah dan mengendalikan dampak kesehatan yang disebabkan karena merokok. Pengendalian dampak kesehatan bukan hanya berlaku pada perokok aktif, tetapi juga perokok pasif dan lingkungan sekitar yang terpapar asap rokok.

Rokok merupakan salah satu zat adiktif yang bila digunakan dapat mengakibatkan bahaya bagi kesehatan individu dan masyarakat. Berdasarkan Peraturan Pemerintah Nomor 109 Tahun 2012 Tentang Pengamanan Bahan yang Mengandung Zat Adiktif Berupa Produk Tembakau bagi Kesehatan, rokok adalah salah satu produk tembakau yang dimaksudkan untuk dibakar, dihisap dan / atau dihirup asapnya yang dihasilkan dari tanaman Nicotiana tabacum, Nicotiana rustica dan spesies lainnya atau sintetisnya, yang asapnya mengandung nikotin atau tanpa bahan tambahan (Armstrong 2010).

Rokok dapat berbentuk rokok kretek, rokok putih, cerutu atau bentuk lainnya. Di dalam produk tembakau terbakar terutama rokok, terdapat lebih dari 4.000 zat kimia berbahaya, diantaranya adalah nikotin yang bersifat adiktif (dapat menyebabkan ketergantungan) yang bersifat karsinogenik. Rokok dapat menyebabkan kanker paru yang merupakan penyebab kematian nomor satu di dunia. Perokok berisiko 2 - 4 kali lebih besar terkena PJK dan berisiko lebih tinggi untuk kematian mendadak (Aditama, T, Y, 2011).

Rumah sakit ini merupakan salah satu rumah sakit yang menerapkan kebijakan KTR meskipun masih berupa himbauan. Penelitian yang dilakukan oleh Dhanny 2011 melihat bahwa ratarata pengunjung rumah sakit, terutama pendamping pasien dengan bebas dapat merokok, baik di dalam ruangan maupun di luar ruangan dan terdapat pengaruh pada tingkat kesehatan.
Kegiatan merokok tetap berjalan meskipun sudah ada beberapa poster larangan merokok terpampang di dinding rumah sakit. Tidak ada peringatan yang diberikan petugas kesehatan kepada pengunjung rumah sakit yang merokok saat itu, bahkan salah seorang petugas kesehatan terlihat berjalan dengan rokok yang menyala di tangannya, peneliti mendapatkan informasi bahwa di seluruh ruangan rawat inap rumah sakit sebenarnya telah ditempelkan himbauan untuk tidak merokok. Namun peneliti menemukan bahwa himbauan tersebut tidak terdapat di seluruh ruangan.

Menurut seorang petugas kebersihan, beberapa kertas himbauan tersebut mungkin sudah rusak dan tidak diganti lagi. Selain itu menurutnya himbauan seringkali diberikan karyawan rumah sakit bagi pengunjung yang merokok di lingkungan rumah sakit, namun tidak dihiraukan. Asbak rokok juga disediakan di beberapa ruangan pegawai di rumah sakit. Ini menandakan bahwa RSU Deli Serdang belum dapat dikatakan sebagai KTR seperti yang telah diwajibkan di seluruh rumah sakit berdasarkan UndangUndang Republik Indonesia Nomor 44 Tahun 2009 tentang Rumah Sakit. Sumatera Utara telah mengeluarkan Perda No.35 Tahun 2012 tentang KTR diwilayah Sumatera Utara. Meski KTR ditetapkan sejak tahun 2012 tetapi implementasinya belum optimal khususnya di RSUD Deli Serdang karena rumah sakit merupakan salah satu tempat yang menjadi wilayah KTR. Secara khusus, kegiatan pengabdian masyarakat bertujuan untuk mensosialisasikan bahaya rokok, kebijakan KTR dan memberdayakan tenaga kesehatan dan masyarakat dalam mendukung pengimplementasian KTR dilingkungan sekitar.

\section{Metode}

Pengabdian masyarakat ini dilakukan di RSUD Lubuk Pakam Deli Serdang. Metode pelaksanaan dengan metode sosialisasi berupa pemahaman tentang kondisi perokok di Indonesia dan tentang KTR. Selain itu dilakukan dengan sesi tanya jawab dan 
wawancara kepada tenaga kesehatan dan pengunjung terkait rokok dan KTR. Pelaksanaan kegiatan ini dibagi menjadi tiga tahapan yaitu, perencanaan, pelaksanaan dan evaluasi. Pada tahap perencanaan meliputi survey lokasi pengabdian dan koordinasi dengan pihak terkait dalam pengabdian. Tahap pelaksanaan yaitu pemberian kuesioner, pemberian edukasi tentang rokok dan bahaya rokok, dan sosialisasi KTR. Tahap evaluasi dilakukan dengan melihat kesadaran tenaga kesehatan dan masyarakat akan bahaya rokok dan peran masing-masing dalam mendukung pengimplementasian KTR.

Berikut gambar singkat metode pelaksanaan pengabdian masyarakat:
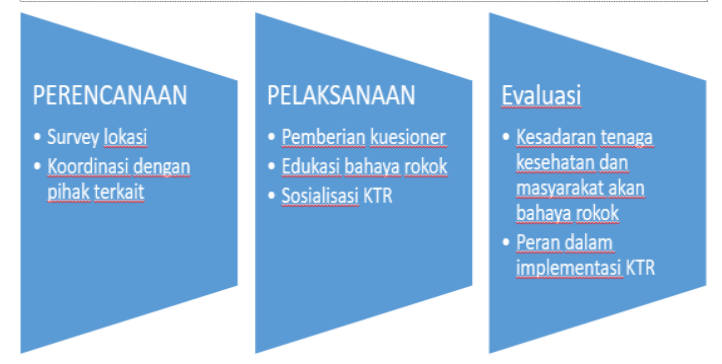

Gambar 1. Tahapan pelaksanaan kegiatan pengabdian

\section{Hasil dan Pembahasan}

Berdasarkan hasil yang diperoleh dari wawancara yang dilakukan kepada responden tentang kebijakan kawasan tanpa rokok dapat dilihat dalam tabel dibawah ini:

Tabel 1. Distribusi Pengetahuan Petugas Kesehatan Tentang Kebijakan KTR

\begin{tabular}{|c|c|}
\hline $\begin{array}{l}\text { No } \\
\text { Informan }\end{array}$ & Jawaban \\
\hline Informan 1 & $\begin{array}{l}\text { Pendapat ku tentang } \\
\text { kebijakan itu.. ya sangat } \\
\text { bagus...ya ia bagus lah ya } \\
\text { kan supaya pasien-pasien } \\
\text { pun terhindar dari } \\
\text { penyakit yang } \text { di } \\
\text { akibatkan oleh si rokok } \\
\text { tadi. }\end{array}$ \\
\hline Informan 2 & $\begin{array}{l}\text { Mmm...kebijakan } \\
\text { itu...saya rasa itu bagus } \\
\text { karena kan dengan } \\
\text { adanya itu kita biar tau } \\
\text { menempatkan jangan } \\
\text { merokok di sembarang } \\
\text { tempat, seperti itu }\end{array}$ \\
\hline
\end{tabular}

Penting ya untuk rumah sakit supaya orang-orang yang merokok sembarang tempat tidak sembarangan lagi.

Informan 4 Ya..menurut saya kebijakan itu suatu aturan yang harus di patuhi ya, apalagi tentang kawasan tanpa rokok itu sangat penting, agar rumah sakit terhindar dari bahaya rokok dan menciptakan lingkungan rumah sakit yang bersih dan nyaman.

Berdasarkan tabel 1 pada Persepsi Petugas Kesehatan tentang Kebijakan KTR Petugas Kesehatan sangat setuju dengan kebijakan KTR di rumah sakit umum deli serdang, berdasarkan wawancara mendalam dengan beberapa petugas kesehatan yang ada.

Tabel 2. Matriks Pernyataan Informan Tentang Tujuan Kebijakan KTR

\begin{tabular}{llr}
\hline No Informan & Jawaban & \\
\hline Informan 1 & Tujuannya ya agar rumah \\
& sakit ini bebas dari asap \\
& rokok. & \\
Informan 2 & Tujuannya agar \\
& ee...masyarakat yang \\
& tidak merokok terhindar \\
& dari bahaya dari asap \\
& rokok itu, seperti itu \\
& kalau menurut saya. \\
Informan 3 & Mmm...kalau menurut \\
& saya tujuannya agar \\
& menciptkan kawasan \\
& yang bersih dari asap \\
& rokok, dan orang-orang di \\
& rumah sakit terbebas dari \\
& asap rokok. \\
& Ya tujuannya emm... \\
& supaya rumah sakit \\
& terbebas dari asap rokok \\
Informan & dan menciptakan \\
& lingkungan yang bersih \\
& dan sehat.
\end{tabular}

Berdasarkan tabel 2 diatas, Berdasarkan hasil wawancara kepada seluruh informan mengenai tujuan dari KTR, maka diperoleh pernyataan bahwa dari 4 orang informan mengatakan 
Received: 04 June 2021 :: Accepted: 29 June 2021 :: Published: 30 June 2021

bahwa mereka setuju dengan KTR tersebut.

Tabel 3. Matriks Pernyataan Informan

Mengenai Pendapat Mengenai Seorang yang merokok

\begin{tabular}{|c|c|}
\hline No.Informan & Jawaban \\
\hline Informan 1 & $\begin{array}{l}\text { Menegurnya, bahwa } \\
\text { efek dari rokok itu } \\
\text { tidak baik untuk } \\
\text { kesehatan }\end{array}$ \\
\hline Informan 2 & $\begin{array}{lr}\text { Biasanya } & \text { kalau kita } \\
\text { sebagai } & \text { petugas } \\
\text { kesehatan ya...kita } \\
\text { melarang rata } \\
\text { mengarahkan } \quad \text { ata... } \\
\text { kepada } & \text { siperokok } \\
\text { bahwasanya wilayah } \\
\text { untuk merokok itu } \\
\text { sebelah sana, gitu... ini } \\
\text { kawasan yang di larang } \\
\text { merokok jadi mereka } \\
\text { tidak boleh merokok, } \\
\text { biasanya } \\
\text { melarang. }\end{array}$ \\
\hline Informan 3 & $\begin{array}{lrr}\text { Mmm... yang pasti } \\
\text { menegur ya... } & \text { atau } \\
\text { memberitahu } & \text { klu } \\
\text { rumah sakit adalah } \\
\text { kawasan tanpa rokok, } \\
\text { jd nggak boleh } \\
\text { merokok disembarang } \\
\text { tempat }\end{array}$ \\
\hline Informan 4 & $\begin{array}{lr}\text { Menegur, } & \text { ya } \\
\text { menegur...bahwa tidak } \\
\text { boleh } & \text { merokok } \\
\text { disembarang } & \text { tempat } \\
\text { selagi masi } & \text { dikawsan } \\
\text { tanpa rokok. } & \\
\end{array}$ \\
\hline
\end{tabular}

Berdasarkan tabel 3 sikap pada penelitian ini untuk menggali pendapat dan penilaian informan tentang kebijakan KTR. Petugas kesehatan menunjukkan sikap yang Positif mengenai seorang yang merokok di rumah sakit umum daerah deli serdang, berdasarkan wawancara mendalam.

Pengabdian ini diawali dengan pembagian kuesioner yang berisi pertanyaan tentang kegiatan merokok, bahaya rokok dan pengetahuan KTR. Keseluruhan tenaga kesehatan dan masyarakat memahami tentang bahaya merokok namun tetap melaksanakan kegiatan merokok dengan alasan kecanduan dengan rokok, dan kebijakan KTR ada 10 masyarakat yang mengetahui tentang KTR dan hanya terbatas pada kepanjangan KTR. Selanjutnya pemberian edukasi tentang rokok dan bahaya rokok. Dalam pemberian edukasi ini sebagian masyarakat terkejut melihat data yang ditampilkan menunjukkan bahwa terjadi peningkatan perokok di Indonesia termasuk wanita dan remaja setiap tahunnya.

Setelah pemberian edukasi tentang rokok dan bahaya rokok dilanjutkan dengan sosialisasi KTR. Sosialisasi diawali dengan pengertian KTR, kerangka hukum KTR secara nasional. Sosialisasi ini memberikan pemahaman bahwa RSUD Deli Serdang memiliki peraturan untuk menerapkan dan mendukung KTR yang dikeluarkan oleh pemerintah melalui Kemenkes. Peraturan tersebut tertuang dalam Undang-Undang Republik Indonesia Nomor 44 Tahun 2009 tentang Rumah Sakit, Perda No.35 Tahun 2012 tentang KTR diwilayah Sumatera Utara dan Pergub No 15 tahun 2014 tentang petunjuk pelaksanaan peraturan daerah tentang pajak rokok.

\section{Kesimpulan}

Keseluruhan tenaga kesehatan dan masyarakat memahami tentang bahaya merokok namun tetap melaksanakan kegiatan merokok dengan alasan kecanduan dengan rokok. Sosialisasi KTR memberikan pemahaman bahwa RSUD Deli Serdang memiliki peraturan untuk menerapkan dan mendukung KTR yang dikeluarkan oleh pemerintah melalui Kemenkes.

\section{Ucapan Terima Kasih}

Dalam kegiatan ini tim pengabdian mengucapkan terima kasih Kepada Institut Kesehatan Medistra Lubuk Pakam, Lembaga Penelitian dan Pengabdian kepada Masyarakat Institut Kesehatan Medistra Lubuk Pakam, Direktur Rumah Sakit Deli Serdang dan semua pihak yang telah mendukung kegiatan PKM ini yang tidak dapat disebutkan satu per satu. 
Received: 04 June 2021 :: Accepted: 29 June 2021 :: Published: 30 June 2021

\section{Daftar Pustaka}

Aditama, T, Y. 2011. Rokok dan Kesehatan. Jakarta: Universitas Indonesia.

Armstrong, Sue. 2010. Pengaruh Rokok Terhadap Kesehatan. Jakarta: Arcan.

Kesehatan, Kementrian. 2011. Peraturan Bersama Menteri Kesehatan dan Menteri Dalam Negeri Nomor 188/MENKESPB/I/2011, Nomor 7 Tahun 2011 Tentang Pedoman Pelaksanaan Kawasan Tanpa Rokok. Jakarta, Indonesia: Kementerian.

Undang-undang Republik Indonesia Nomor 44 Tahun 2009 Tentang Rumah Sakit

Undang-Undang Republik Indonesia Nomor 36 Tahun 2009 Tentang Kesehatan

Undang-Undang Republik Indonesia Nomor 39 Tahun 1999 Tentang Hak Azazi Manusia 